\title{
MĀORI BUSINESS NEWS IN THE MASS MEDIA
}

Tim McCreanor, Anna-Lyse McManus, Angela Moewaka Barnes, Jenny Rankine, Belinda Borell \& Ray Nairn*

\begin{abstract}
Despite numerous historical and contemporary demonstrations of their business acumen, hegemonic discourses represent Māori as dishonest, lazy, incompetent and unfairly privileged in this domain. We studied the items about Māori business in a large representative national sample of newspaper coverage gathered in 2007/8 using content, thematic and discursive analyses. From these data we conclude that mass media newspapers in Aotearoa reproduce hegemonic views through very low levels of coverage and frequent recourse to Pākehā expectations about Māori business. The overall effect is to minimise, marginalise and denigrate important Māori contributions to this vital arena of national life.
\end{abstract}

\section{INTRODUCTION}

Commerce formed one of the key points of contact between Māori and the wider world in the decades following the first visits to Aotearoa New Zealand by European explorers in the 18th century (Belich, 1996; Salmond, 1991). European belief in their material superiority manifested itself in the inclusion of 'trade goods' among their provisions and many earlier accounts detail avid exchanges between Māori and the newcomers (Earle, 1909; Nicholas, 1817; Polack, 1974; Salmond, 1991). As John Ward, Secretary of the New Zealand Company, noted with enthusiasm before the commencement of colonisation in 1839: 'The natives enter largely into commercial transactions in the sale of flax, timber, potatoes and pork, with the ships that visit their coasts and such is their credit that some of them have been trusted with $£ 1500$ worth of goods' (Ward, 1839:70).

\footnotetext{
* Whariki Research Group, Massey University, Auckland, New Zealand
} 
Māori entrepreneurship led to rapid adoption and expansion of new crops, technologies, methods of production and markets (Petrie, 2006; Simpson, 1986). In the 184 os Mãori commerce accounted for $95 \%$ of the gross national product of the colony and Māori had large acreages under wheat, potatoes and fruit trees, ran significant stocks of cattle and pigs, and controlled a fleet of trading vessels that accessed markets in Australia and even California (Simpson, 1986).

But the optimistic framing of Māori commerce did not last long as European capital sought to maximise profits (Belich, 1996; King, 2003), the settler government set about redressing the cost of establishment (McLintock, 1958; Walker, 1990) and settlers sought livelihood and wealth in Aotearoa New Zealand (King, 2003). Many of these developments were wrought at the expense of Māori resources, economic practices and labour by the imposition of globalised standards upon local practices (King, 2003). In particular the rules of the marketplace and the principles of competitive supply and demand were applied and backed by law and force as required (Belich, 1996; Simpson, 1986).

As immigration and settlement increased rapidly in the decades after 1840 it seemed that the whole country came under what Spurr (1993) has referred to as the colonial gaze, where few potential resources escaped attention and land was a high priority. A traveller's tale from a provincial newspaper illustrates the commercial imperative that drove settler aspirations:

It is really painful to be reminded that all the natural advantages which New Plymouth possesses are counterbalanced by the presence of an overwhelming native population. The little town is full of soldiers; not a building is in progress; not a sign of animated business is visible. The settlement possesses the dimensions of about two English parishes, and through out its small extent is cultivated to green and smiling farms; but outside the boundary, a wide district of equal capability still frowns in its native uselessness, for the Māori refuses to sell. (Taranaki Herald, Volume viI, Issue 316, 21 August 1858, p.1)

Early Pākehā representations of Māori were generally denigratory, patronising and exclusionary (Ballara, 1986; Colvin, 2010; McCreanor, 1997; Petrie, 2006) and their accounts of Māori economic activity shifted to increasingly portray Māori as lazy, dishonest, greedy, incompetent and criminal (Nairn \& McCreanor, 1991; Petrie, 1998). Pākehā discourses, such as those depicting resources that were not exploited by Mãori as 'waste', imagery such as 'ragwort and blackberry,', along with notions that Māori had unfair advantages such as 
free resource access and communal labour, became predominant (Ballara, 1986).

In this paper we explore the tensions between these poles of Pākehā discourse about Māori commerce as they are represented in contemporary mass media in Aotearoa. Two centuries of interaction have vastly changed the basis and nature of relations between Mãori and Pākehā and the overall economic balance has clearly tipped in Pākehā favour. We will argue that while Māori have a long history of highly successful commerce that has persisted despite the ravages of colonialism, the recent history of Māori development of economic resources alongside successful claims to the Waitangi Tribunal and political gains on a number of fronts mean that Māori commerce is newsworthy again. We present analyses of items from a representative sample of newspaper stories gathered in $2007 / 8$ and use these materials to interrogate the nature and implications of these representations of this critical aspect of the Māori world and their place in the life of the nation.

\section{COLONISATION AND MĀORI COMMERCE}

In the earliest years of colonisation, the challenges of settler survival and prosperity created venal tensions over resource use, land acquisition, labour and commercial markets, as well as more subtle clashes with whanau, hapu and iwi around the protocols of trade, commerce and management of resources. These dynamics led to struggles and open warfare as the cultures jostled for power and control, culminating in localised military conflicts and ultimately in the New Zealand Wars in the period 1843-1916 (Ballara, 1986; Belich, 1986; King, 2003; Simpson, 1986). In the 188 os and 9os, with Māori power ground down (though undefeated militarily) by the economic and human costs of war, infectious diseases and the increasing alienation of their territories, entrepreneurial activity waned.

Petrie (2006) has produced an historical account of Māori commerce from early contact through the settlement and colonisation years of the 19th century. She argues that the hallmark of Māori business was its adaptability, firstly to European trading practices and technological innovations but successively to mass settlement and the detrimental effects of colonisation including land and asset loss, social disruption and cultural change. Māori business leaders invested in technology and infrastructure that they meshed with the traditional cooperative labour practices of whanau, hapū and iwi, to engage competitively in local and international markets. The depredations of colonisation through warfare, land and resource loss and sheer weight of numbers, all contributed to the demise of Māori economic power and the loss of vital commercial re- 
sources by the 1860 , two decades after the signing of Te Tiriti o Waitangi (Belich, 1996; King, 2003; Simpson, 1986).

As the Pākehā colonial project (McCreanor, 2009) fuelled by mass immigration began to turn the balance of power against Mãori, there was a shift from nominal sovereignty toward substantive sovereignty (Belich, 1986) for settler interests. Control of the colonial government by settlers placed policy and decision-making firmly in the hands of Pakeha, and effected settler control of the fledgling state (Durie, 1998; Walker, 2004). As the combined effects of political and economic control bore fruit, Māori whanau and hapū were steadily and inexorably marginalised in all aspects of colonial life and especially in economic development (Petrie, 2006). At first they were consigned to stagnation in tribal lands or ignored in the hinterlands of Pākehā development; later in the mid-2oth century, they were drawn into economic dependence as an urban labour force (King, 2003).

More recently, Pākehā common sense has assumed that Māori were inherently unsuited to business, as a result of individual and cultural characteristics, and destined to futures as working class citizens dependent upon selling their labour to Pākehā capitalist enterprise (Robson, 2007; Spoonley, MacPherson, Pearson, \& Sedgwick, 1984; Walker, 2004). Latterly, particularly as some redress for colonial damage and return of illicit resource confiscations have taken effect, whanau, hapū and iwi have pushed commercial development, challenging Pākehā stereotypes as Māori make their way enthusiastically in a range of business applications and opportunities (Te Puni Kōkiri, 2011).

\section{CONTEMPORARY MĀORI COMMERCE}

Recently, knowledge of early Māori commercial success has been noted and drawn upon as a lever for contemporary Māori economic development (Petrie, 2006). These trends were boosted by a report from the Global Entrepreneurship Monitor (GEM), showing that New Zealand lead the world on the measure and that Māori were the most active group within the population (Jackson, 2007). Subsequent research (Frederick \& Henry, 2004) indicated that the original findings were optimistic, and critique particularly by Devlin (2007) around their definition of entrepreneurship argues that it is inadequate to support the conclusions drawn.

Recent statistics from Te Puni Kōkiri (2011) show a total Māori commercial asset base of $\$ 16.5 \mathrm{~b}$, making up about $1.5 \%$ of the total value of the Aotearoa New Zealand business sector, at a time when Māori comprise at least 15\% of 
the population. In 2006 more than 21,00o Mãori were either employers or self-employed. Further, the investment structure of Mãori commerce is quite different from that of settler business, with more than $50 \%$ concentrated in the primary sector compared to $10 \%$ for settler commerce, and $40 \%$ of Maori investment in the tertiary sector compared to $80 \%$ of settler investment, in 2006 .

These figures clearly indicate that Mãori commerce represents a small proportion of the national economy. However, the large-scale theft and confiscations of Māori assets during colonisation, the steady erosion of the remainder through aggressive commercial acquisition, and government willingness to use legislation to force further alienation in 2011, means that the Mãori estate is a fragment of what it should be. For this reason the process of Treaty claims to the Waitangi Tribunal represents an important economic variable through which whanau, hapū and iwi can obtain redress that can help restore their economic base. In the mid-199os in an effort to secure an end to treaty claims, the government floated the notion of a 'fiscal envelope' that would effectively cap the size of reparations at $\$ 1$ billion. In reality this ceiling cannot hold, with claims already well in excess of the cap. Moreover, it is acknowledged that what has been transferred represents but a small percent, in fiscal terms alone, of the actual value of the asset base pre-colonisation (Jackson, 2007).

Key settlements, especially those that have occurred since 2006, entail sums which have potentially increased the size of the Mãori estate beyond the Te Puni Kokiri estimates. The 1989 and 1992 Māori Commercial Fisheries Settlement transferred $10 \%$ of fishing quota, shareholdings in fishing companies and $\$ 50$ million to Te Ohu Kaimoana (Te Ara, 2011) which by 2004 had assets of $\$ 750$ million available for hapu and iwi commercial development. The socalled 'Treelords' settlement over central North Island forests was in excess of half a billion dollars. Such resources are flowing into multiple Māori ventures, so in this sense the Māori economy is one of the growth areas of national enterprise.

In a more focussed study, McIntosh et al. (2004:349) argue for the need to reframe Māori tourism operations in terms of Māori values, as 'Māori-centred tourism'. Discussing principles such as tino rangatiratanga (self-determination), kaitiakitanga (guardianship), whanaungatanga (relationships), manakitanga (hospitality) and wairuatanga (spirituality) they conclude: 'The incorporation of Māori cultural values and practices into commercial development is advocated as essential for sustainable, Māori self-determined development' (Ibid). We turn now to examine ways in which these developments and aspirations are covered in mass media. 
An early study of New Zealand newspapers by Thompson (1954) reports a number of themes in representations of Māori. In regard to the commercial sphere, a central idea is that 'Māoris are lazy and irresponsible': this view was seen as reflecting broad public opinion and linked to other negative themes around alcohol, health, housing, education and land use. Thompson reported headlines including 'Māori Could Do More for Himself'; Māori Must Be More Self-Reliant' which signal perceptions of improvidence and lack of initiative. These features link to themes running through a body of Pākehā submissions to the Human Rights Commission reported by Nairn and McCreanor (1991) that re-produce the notions of laziness but also add representations of dependency and dishonesty. Inter alia Devlin (2007:411) refers to 'a negative, stereotypical view that Māori business is usually bad business - a view mainly attributed to the media.'

This theme has appeared in several other research sources and we are interested to test it against our sample. For example Crombie et al. (1972) used discursive methods to compare New Zealand Herald editorials about Tainui and Air New Zealand business issues and found evidence of 'racist discourse' that maintained the oppressive status quo of power relations between Pākehā and Māori. Editorial writers were demonstrably using different discourses to describe and subtly denigrate Māori business issues in ways that were reported to impact negatively upon their confidence and business efficacy.

A report from Kupu Taea (Rankine et al., 2008:11) analysed news items reporting on Māori commercial activity from a large newspaper sample. They found a common theme which they termed 'Financial Probity' that 'depicts Māori as having unfair access to diverse funding sources and support for projects that do not deserve it. It also constructs Māori as corrupt or economically incompetent.' This study also found that Māori business stories were rare and produced a preponderance of accounts of Māori fraud and Māori business failure (Rankine, et al., 2008).

Liu (2009:426) found that new Chinese settlers to New Zealand were, through their use of Chinese language newspapers, exposed to 'negative and biased Māori representation' that included the hegemonic notions that Maori are lazy, dishonest and improvident (and thereby commercially suspect). She attributed this finding to the fact that these newspapers simply translate Pākehā press items rather than gathering news independently, and also found in a follow up survey that participants held negative views of Māori. 
Together these sources suggest hegemonic thematic elements that construct Maori and Maori commercial activity as inherently problematic, morally suspect and potentially risky - bad business. We investigate the influence of this theme within the business-related stories of our sample.

\section{METHODS}

Between November 2007 and April 2008 our project collected a representative sample of print, radio and television news items relating to Māori and Māori/ Pākehā relations. Three 'constructed weeks' (Lacy, Riffe, Stoddard, Martin, \& Chang, 2001) made up of twenty-one sampling days (3 of each of the days of the week) were randomly selected and data collected from all available newspapers, radio stations and TV newscasts.

For the newspapers (the focus in this paper), a newsmonitoring service gathered print data using a set of 15 keywords or phrases, including Māori, iwi, hapū, whanau, Treaty of Waitangi, Māori-Pākehā relations. Every New Zealand daily, bi-weekly or weekly title (a total of 120) was sampled, resulting in a raw data set of 1,621 items. Photocopies of each story, with headlines, photographs, page numbers and a graphic of location on the page were supplied. Stories that had a significant focus on Māori issues were selected and those where Māori interests were incidental were excluded. A final database of 858 print media items was assembled, based on first-cut selections by two researchers independently, after discussions of debateable items by the whole team.

An informal check of the effectiveness of the sampling (hand-counting crime stories in two of the sample newspapers across the sample days) suggested that our database underestimated actual coverage by approximately $15 \%$. Most of the stories that had been 'missed' were about individuals who were only identified as Mãori by their Māori names or because they were known to be Māori; either way the story fell outside the parameters of the keyword search.

Items were then coded into topic areas that accounted for all 858 items; Art and Crime stories were the most common. Business stories were relatively rare with just 25 items in this category. We have analysed this database using three different methods to create a broad understanding of its characteristics. Each of these methods in outlined briefly below.

\section{Content analysis}

The 25 stories in the category of Business were coded in an Access database 
by page number and publication, whether daily or non-daily, the author, and the type (news or feature/current affairs), and origin of items. Items were also coded for the number of people cited, whether sources were available for comment, the ethnicity, role and gender of sources, the order in which sources were quoted and the number of sentences per source.

Where the ethnicity, role and gender of a source were not a matter of public record, sources were contacted by phone. Up to 20 phone calls were made before some sources could be contacted. Where sources were unavailable, occasionally a close relative or work colleague was able to supply this information.

We used a framework based on the Treaty of Waitangi as the key influence on the relationship between Maori and settler to categorise newspaper sources of information. The Treaty was signed between the Crown (later the Government) and iwi and hapū. We therefore categorised sources as representing iwi/hapu and Government, which included Government MPs, department spokespeople, local body politicians, and police or armed forces spokespeople. Non-governmental organisations (NGOs) were categorised as either Māori or tauiwi (non-Māori). However, non-Government MPs made up such a large block of sources that they were categorised separately. The last category was unaffiliated individuals. Each item was coded for all these variables in an Access database, and results outputted into Excel spreadsheets.

\section{Thematic analysis}

This analysis examined all 25 business stories to provide a descriptive overview of the mass newspaper coverage of Māori business activity. Part of this analysis entails relating the coverage to contextual ideological themes as recommended within both media studies (Philo, 2007, Van Dijk, 2000) and thematic analysis (Braun \& Clarke, 2006). In addition to the Maori Business theme outlined above, key discursive elements that emerged from the thematic analysis include: One People - Maori identity undermines national cohesion; Māori Culture - Maori ways are too simple for the modern world; Good Māori/Bad Māori - Maori either fit in or fail in NZ society; and Privilege - Māori have unwarranted and inequitable rights (McCreanor, 2008).

\section{Discursive analyses}

We chose two items to illustrate ways in which the discursive detail of reporting of business news served to reproduce problematic or damaging representations of Māori. We used the deconstructive close reading processes of 
discourse analysis (Fairclough, 1995; Potter \& Wetherell, 1987; Van Dijk, 1988) to show the ways in which choices of vocabulary, structure and rhetoric influenced meaning-making and interpretations of these items.

\section{FINDINGS}

In this section we present the data analysis for each of the methods deployed, before discussing the implications of these findings.

\section{Content analysis}

The 25 Business items made up a little under $3 \%(25 / 858)$ of the total sample well short of the 50 stories about sport or the 100 stories on crime revealed by the wider analysis of the data.

They were published by 17 newspapers (14\% of those contributing to the sample) and the majority (68\%) were in daily papers. The largest number of stories for a single paper was 5 in Hawkes Bay Today followed by 3 in the Dominion Post and 2 in the New Zealand Herald and the Rotorua Daily Post. Two business stories named no sources for their information, so that the business topic had, with several other topics, the smallest group of unsourced items. The remaining 23 business stories used 46 sources, making an average of $1.84(46 / 25)$ across all the business stories, higher than the average of 1.7 for the whole sample $(1449 / 858)$.

These business stories made up a low proportion of stories with only Pākehā sources making up $2 \%(5 / 215)$ compared to $25 \%$ for the whole sample. Out of the 43 business story sources where ethnicity was known, 49\% (21/43) were Pākehā and 49\% (21/43) Māori. Source roles were evenly divided between unaffiliated individuals (12); Māori NGOs (11); Tauiwi NGOs (10) and Crown spokespeople (9). Iwi and hapū representatives (4) were quoted more rarely. Seventy-eight percent $(36 / 46)$ of sources were male, higher than the proportion of male sources for the whole sample of $63 \%$ (917/1449).

Only one Mãori business story (4\%) was printed on the front page of a newspaper compared with $8 \%$ for all other Māori stories (68/858). News pages 2 to 5 carried $28 \%$ of business stories (compared to $40 \%$ ); news pages 6 to 10 hosted $4 \%(21 \%)$, with four percent on non-news pages $(7 \%)$. The highest proportion $(48 \%, 12 / 25)$ of business stories were printed on or after news page 11 (compared to $23 \%$ ), and only three stories (12\%) were printed in the business pages. A higher proportion ( $92 \%$ ) of business stories were written by each paper's own 
journalists than for the whole sample (75\%).

Thematic analysis

In this section we attempt to provide a sense of the ways in which items drew upon hegemonic themes without showing the detailed analyses from which these claims are derived in order to provide the reader with an overall sense of the sample. In the section that follows we provide an illustration of this underlying method using two items which are subjected to discursive analyses. The list in Table 1 illustrates the distribution of the 25 stories across key topic areas. A brief overview of the news items and themes running through the materials in each topic area is then given.

Table 1. Topic coding of business stories $(N=25)$

\begin{tabular}{l|c}
\hline Topic & Stories \\
\hline Alliances & 2 \\
Construction & 2 \\
Energy & 1 \\
Farming & 6 \\
Fishing & 3 \\
Forestry & 1 \\
Law & 1 \\
Media & 1 \\
Research & 1 \\
Small & 2 \\
Tourism & 5 \\
\hline
\end{tabular}

\section{Alliances}

Two nearly identical stories in the Nelson Mail and Timaru Herald cover a strategic agreement between Ngai Tahu and Tainui. The emphasis is firmly on the size of the asset base that the collaboration creates and the power already wielded by both groups.

Two of the country's most powerful iwi joined forces at Timaru's Arowhenua Marae yesterday, bringing together more than a billion dollars worth of combined assets, in what is being viewed as a historic occasion by both sides. (Nelson Mail, 24.11.07, p14)

There is an implied sense of threat (though possibly some admiration as well) from 'combination' as a source of cartel-like or at least unusual advantage, 
perhaps evoking Maori corporate machinations inherently problematic for 'One People' ideology.

\section{Construction}

In relation to the topic area of construction, we found stories from Napier and Tauranga which carry details about iwi-led housing developments. A Bay of Plenty Times item reports commencement and progress on a joint venture commercial retirement village in which the landowning Mangatawa Trust will return dividends for its 600 beneficiaries. A Hawkes Bay Today story is about a joint venture between Ngati Kahungunu and the construction company, but in this instance the development is for iwi housing in the suburb of Flaxmere.

Both are examples of the business success genre of Māori development in which tangata whenua are portrayed as competent and collaborative. The 'win-win' scenario (at least within the Pākehā commercial paradigm) of profit, beneficiaries, dividends also draws on the notion that they are 'doing what they should' (providing their people with housing) with their 'privilege'. However, there is a lingering sense of 'privilege' since both stories indicate or imply the use of ancestral land, which gives an edge over other commercial developments since it obviates the need to raise capital to purchase the land for the venture.

\section{Energy}

This highly positive story in the Taupo Times is about joint venture between iwi and Mighty River Power for a geothermal power station to the north of Taupo: 'Joint venture director and Mighty River Power chief executive Doug Heffernan says the signing of the contract is a 'fantastic' step forward in the involvement of Māori in the development of the country's geothermal resource' (Taupo Times, 3.4.08, p15).

The notion of implicit advantage is demonstrated in this story through the comments made by Māori spokespeople, who state that collaboration among iwi trusts played a critical role in the successful outcomes. There is an additional theme relating to 'Privilege' here in that Māori claims to energy resources such as coal, oil, gas and steam are even more widely discounted than their claims to more tangible assets such as land and forests.

However, within Māori paradigms that value Papatuanuku as mother, the exploitation of energy resources for profit is problematic and requires more ac- 
tive and extensive debate, clarity and consensus than might be expected from Mighty River Power.

\section{Farming}

These six stories about Māori dairy farming appear largely in local North Island papers; five focus on the Ahuwhenua Trophy competition, with a second story covering the Taranaki drought.

The Ahuwhenua stories explain the basis for the competition (including its instigation by Sir Apirana Ngata), discuss past winners and profile some of the finalists.

The Ahuwhenua Trophy ... Awards executive management committee chairman Kingi Smiler says dairying is critical to the success of the New Zealand economy and Māori dairy farmers can feel proud of the contribution they are making to the industry's success. (North Waikato News, 5.12.07, p18)

While clearly a positive success story, the spokesperson emphasises the Māori contribution as tributary to the national good rather than in terms of any Māori development aspirations. There are also links here to the 'Privilege' and 'Māori Culture' themes (why can't they compete in mainstream?) and the exclusivity of the competition means that the Trophy is easily seen as achievement in a small, sheltered pool. What is missing in these items is contextual information about why Māori have a separate competition and what is entailed in bringing traditional lands into commercial production.

Interestingly, the story about drought in Taranaki in the Dominion Post also pulls on the 'Privilege' theme. It notes gratuitously that the district's largest producer is a Māori incorporation that runs on ancestral lands, allowing access to the highly profitable industry without having the usual burden of debt.

\section{Fishing}

Three items about Māori involvement in commercial fishing in national and provincial papers cover two different stories. Together these stories present a strong theme of Māori success, competence and commercial resilience.

Two stories are about opportunities for fish exports to China in the wake of the NZ-China Free Trade Agreement; one of these is explored in detail using discursive methods below. The excitement about the potential revenues from 
these arrangements is mediated by the understanding that these Māori ventures are founded upon quota derived from the Waitangi Tribunal Fisheries claim and Treaty settlements ('Privilege'). The remaining item is a notification of regular board changes at Aotearoa Fisheries Ltd.

\section{Forestry}

This is a single story about a training scheme for forestry workers in Northland where there is a chronic shortage of skilled labour. All candidates on the course described were Māori and 10 of 13 graduated and obtained contracting jobs with forestry harvesters.

\section{Law}

This single story links legal aid, particularly to Māori law firms working for iwi and other clients making claims, to the Waitangi Tribunal. This item is the focus of discursive analysis below.

\section{Media}

In this single story, the CEO of Māori Television Service (мтs) makes a preemptive strike against the conventional discourses of 'Māori Business' canvassed above, to emphasise growth, audience and success.

'Most fair-minded Kiwis see we're working hard, we're fiscally responsible, we run a good tight business and we're delivering on our statutory obligations.' Two-thirds of the broadcaster's viewers were non-Māori and its audience size was growing. (Independent Financial Review, 9.04.08, p27)

The state-funding of мтs (arising from Te Reo claim to the Waitangi Tribunal) means that almost any story about the channel can be referenced to the 'Privilege' theme; MTs would not exist but for the special relationship between Maori and Crown.

\section{Research}

This story is about Meto Leach and Crop and Food Research collaborating to make use of Māori knowledge of biodiversity in the pursuit of culinary ingredients: 'Flavours used in traditional Māori cooking-and possibly some brand-new flavours-could soon enter trendy cuisine and earn export dollars.' 
(Dominion Post, 5.12.07, p12)

In spite of the success and optimistic tone, the piece struggles against the 'Māori Culture' theme, which suggests that Māori have little to offer Pākehā traditions, except in the realm of the 'exotic'. The use of the word 'traditional' locates Māori cooking and flavours in an essentialised past. The item signals disdain via the use of the term 'trendy' (implying transience) and the export orientation that suggests that whatever ingredients might be promoted will not be to local taste, and are more about earnings potential than cultural enhancement. Māori culture/knowledge is only of value if it is harnessed/commercialised and therefore made 'relevant' in contemporary times.

\section{Small}

There are two stories about highly successful Māori small businesses in floristry and honey. The Ngati Kahungunu apiarist's tale is a prime example and his commitment to Māori is clear and articulate.

Wherever possible, Mr Watson prefers to involve Māori. 'It's better than getting into dope, I tell them,' he says. He believes Māori rights to manuka are protected under the Treaty of Waitangi and that Māori should have first rights to place their hives on Conservation Department land. (Dominion Post, 26.4.08, p5)

To name the Treaty and claim rights in this way evokes the 'Privilege' theme and undermines the 'One People' ideology, as well as challenging the competitive ethos of commerce, positioning this leader/businessman as Other. The notion that he 'prefers to involve Māori' infers that he employs by ethnicity, which carries the taint of nepotism, part of the 'Maori Business' theme.

\section{Tourism}

There are five tourism stories about successful operations, sector development, management and marketing. Sometimes these tensions arrive at interesting juxtapositions with Mãori stressing diversity while the Crown position emphasises uniformity and fit within the national frame: 'Our mission is to demonstrate leadership and act as a central communication hub that assists Māori tourist operators to better co-ordinate their efforts and collaborate with other industry players, locally, nationally and internationally'. (Wanganui Chronicle, 29.04.08, p3) 
There are also stories about the award-winning Tamaki brothers' operation in Rotorua, the launch of the Māori Tourism manual covering 100 businesses and a northern hemisphere promotional tour by Waka Tai a Mai, a group of five Tai Tokerau businesses. Overall tourism is a sector in which Māori excel in a competitive market model based on evidence of tourist satisfaction and the importance of authentic Māori cultural products.

The thematic analyses presented above reveal that contrary to the findings of Rankine et al. (2008), the stories in this sample about Māori business are mainly positive. Absent were stories about dishonesty, corruption and incompetence in business. However, as noted above, our hand count check of the sampling methodology showed that stories about Māori crime were undercounted as they often did not include any of the key words used in our search criteria.

As might be predicted from the Te Puni Kōkiri analysis referred to above (TPK, 2011), most items focus on primary industries where most of the Mãori business activity is centred. This may be considered as aligning with aspects of the 'Good Māori' (McCreanor, 2008) theme that argues that as long as they are hard at work on their resource base, Māori can be considered worthy citizens, avoiding the stigma of poverty and dependence. However, along with the under-representation there are also themes of implied threat and assets unfairly attained that can be described through use of discursive analyses as detailed below.

\section{Discursive analysis}

In this section we consider two of the database items in a fine grained analysis that highlights more subtle meanings that underlie the surface structure and contribute to the meanings available to media audiences. In this work we rely upon some sense of the discursive resources of the hegemonic account of Māori and business provided above, as background to the interpretations that we provide. Our argument is that the availability of such resources encourages the writing and reading of particular or stories in ways that will unfairly query, denigrate and marginalise Māori commercial enterprises.

\section{Ngai Tahu fish exports to China}

On the face of it this is a strongly positive story about a highly successful Māori business with very good prospects in important new markets. It is also reported by the Herald's Mãori Affairs staffer, so perhaps there is an expectation that the coverage would be complimentary. We reproduce parts of the 
article for detailed analysis.

Tribe fishing for new contacts by Yvonne Tahana

China is a land of opportunity which could offer huge growth, says Ngai Tahu Seafood

(caption 1) Rich picking: Ngai Tahu Seafood already exports more than $\$ 100$ million worth of live lobster to China annually.

(photo caption) Geoff Hipkins.

On the back of the free trade agreement Ngai Tahu Seafood is going on a fishing trip to China which it hopes will be worth hundreds of millions of dollars.

This weekend general manager Geoff Hipkins is following up Ngai Tahu Holdings' chairman Wally Stone's visit as part of the New Zealand Government delegation.

The tribe's fishing arm exports more than $\$ 100$ million worth of live lobster to China annually, and the superpower also takes a significant portion of paua product. (NZ Herald, 9.4.08, p5)

There are, however, nuances that suggest that somehow the obvious achievements of Ngai Tahu Seafood are not entirely earned via the ideological tenets of good business - skill, knowledge, calculated risk and hard work. Although it is not raised overtly, the context of Treaty of Waitangi Fisheries Claim settlements underlies many Pākehā readings of the piece. Despite the rigour and justice of the Tribunal process there is a commonplace feeling that Māori got something - fishing quota - for nothing, exemplifying Maori Privilege. The reported commercial outcomes evoke Pākehā resentments that undermine affirmative understandings of Ngai Tahu business acumen.

The use of the word 'fishing' in the headline (a common headline pun) subtly denigrates the market development that the company general manager is describing. Fishing is after all located in the unpredictable context of animal behaviour and the endlessly variable patterns of weather, tides and seasons, where even the most skilled practitioners will own to elements of luck and chance. Colloquial metaphor uses 'fishing expedition' as a description of guesswork or intuitive scoping that is far removed from systematic, logical processes 
resonating with elements of the theme of Maori Business outlined above. The word could easily have been substituted for another such as 'pursuing' or 'seeking' that are entirely congruent with the story.

Both the introductory sentence and the caption that follows emphasise the opportunistic, lucky chance elements; 'Rich picking' in particular conveys a sense of gain made easily without strenuous effort being part of a market situation where supply not demand is a key feature. Then the first paragraph introduces another element through the phrase 'on the back of' which evokes the notion that Māori efforts are dependent or even parasitic, rather than wrought in the fires of the competitive free marketplace. This is reinforced by the following sentence which places the initiative within the context of a government trade mission to China while the subsequent sentence reiterates the value of the company, emphasising how well Ngai Tahu have done out of the Treaty settlement and keying the 'Privilege' theme as well as the 'Good Mãori/Bad Māori' theme through the manifest success in market terms.

Much of the remainder of the article is given over to the general manager's enthusiastic optimism about the prospects for the company but this has now been set in the frame created by the opening passages.

In a country with 1.3 billion people, the deal had 'amazing potential', Mr Hipkins said. 'The sky's the limit really. To me, it's a land of opportunity. Demand is not an issue, supply is'.

They are a nation of seafood eaters. Now that the free trade agreement is signed we have a clear path [in that] there will be no tariffs on seafood in five years' time. It's given us a real sense of excitement.

[9 sentences omitted]

For example, Hipkins' take on the trade mission - which he describes as 'a catalyst' in a subsequent sentence - is overshadowed by the dependence trope of the Good Māori/Bad Māori theme. The phrase 'clear path' speaks about unimpeded access to an opportunity that has been created by the Crown. He also refers to the 'Ngai Tahu economy' which conflicts with the 'One People' theme and carries threatening undertones of division and privilege. In the context of the broad sweep of opposition to Māori-driven and controlled activities, 'Maori business', these statements are easily heard as greedy self-interest, given that the profits from what is hegemonically regarded as a 'New Zealand' resource - fish - will go to Ngai Tahu shareholders alone. 
Legal Aid to Māori Law firms

A less nuanced construction is available from analyses of an item about the distribution of legal aid to law firms in the Dominion Post of March 12, 2008.

This is a locally written story in a national paper focussing on local concerns. The journalist provides much of the copy, particularly in the first half of the piece, and sources subsequently confirm the writer's interpretations of the data about legal aid.

Rotorua law firm receives $\mathbf{\$ 1 . 8 m}$ aid - Abigail Caspari

Pullquote: 'At the moment the amount of work is pretty high.' David Rangitauira, Rangitauira \& Co

Subhead: Payments: Firm fifth in NZ for legal aid payouts

Rotorua law firm Rangitauira \& Co received \$1.8 million in legal aid payments in the past 18 months, the fifth highest pay-out in the country.

Most of the $\$ 1.8$ million received by the Rotorua law firm from the Legal Services Board was related to Waitangi Tribunal claims throughout the Central North Island, National Park, Whanganui River district and Northland.

[2 sentences omitted]

The impetus for the item is puzzling in the sense that the focus is firmly upon Māori law firms with the headline singling out one for particular attention on account of the otherwise unremarkable distinction of being 'fifth in NZ' in payouts. At paragraph 2 however the revelation that the funds support claims to the Waitangi Tribunal give some sense of the rationale, but acknowledgement of the scope of these actions is fleeting and minimal. There is an absence of coherent contextual information that could explain the size of the allocations which relate to multi-tribal actions to the large Crown forests of the volcanic plateau (the 'Treelords' claim) as well as other claims, driven by the political need of government to complete the Treaty settlements process. As a result there is a rhetorical tension that draws upon the trope of the Treaty grievance 'industry'. A subtext in this hegemonic discourse is that the link between claimants and lawyers entails a kind of corruption that ensures that 
'Māori Business' will profit handsomely whatever the outcome of the hearing.

Almost \$13 million was paid out in legal aid to the 45 law firms in Rotorua, Taupo, Whakatane and Tokoroa in the past 18 months, according to figures released by the Legal Services Board.

Nearly \$9 million was paid out to Rotorua's 23 law firms and seven of the region's top legal aid earners for the past 18 months were from Rotorua including the top three-Rangitauira \& Co, Te Nahu Law and Lance \& Lawson.

It is not the first time Rangitauira \& Co have received such a high payout.

In the 2003/2004 year the Rotorua law firm received nearly $\$ 1$ million, the second highest pay-out in the country.

The discursive force of the item arises from its repeated highlighting of sums of money in the millions of dollars as earnings associated with Waitangi Tribunal claims in the case of two Rotorua law firm with Māori names. The final sentences in this segment highlight the fact that Rangitauira \& Co have made this list before, as if they are somehow repeat offenders.

Overall the frame provided by the journalist in the first half of the article is one in which Māori law firms are seen to be obtaining large sums of public money; the discourse of the Treaty 'gravy train' with its implied corruption and impropriety are never far away.

A principal of the firm, David Rangitauira said he was not surprised or shocked at the amount of legal aid payments his firm, which has seven lawyers, received.

'It was a shock [2003/2004] but it is not a shock now. At the moment the amount of work is pretty high.'

Hemi Te Nahu of Te Nahu Law was surprised at the amount of legal aid payments his law firm had received.

However, he did not think it was too high compared with other firms.

[5 sentences omitted] 
The Māori sources, who are not quoted until more than halfway through the piece, have to struggle against these features and present as though caught in the headlights, explaining, rationalising, stating that they are 'not shocked' as if they should be. Te Nahu's explanation of the use of these monies reinforces this impression with a scrambling, over-detailed (costs) account that ends with the somewhat irrelevant comment about how time-consuming the cases are.

This may serve to deepen the impression that there is feather-bedding at work or at least that there is something to hide in the sense that 'he doth protest too much. There is a hint also of padding expense accounts with the detailed provision of what legal aid can cover including 'costs relating to travel, accommodation and food.' Throughout the piece, key elements of the 'Maori Business' theme can be seen to be at work discursively constructing legitimate commerce as inherently problematic.

\section{DISCUSSION}

The most salient feature of this survey of business stories in a representative sample of newspaper coverage of Māori stories is that items about Māori business make up less than three percent of the sample. Twenty-five stories (half of which were carried by just four papers) over three production weeks from 120 publications means that most would have no sustained coverage of Māori business activity at all. Gerbner (1972:44) referring to the depiction of women in American television has stated 'absence means symbolic annihilation' and this would appear to be a classic example of the phenomenon in relation to indigenous people.

Perhaps it is not surprising in one sense because most of the stories that appear in our database are actually rather good news, which has low priority within conventional news values. If this ideology and the fundamental racism of the media could be turned around, there is the potential to do much in fairly representing Māori aspirations in the realm of economic development and self-determination (Jackson, 2007), which is the perfect foil to the thematic account of 'Maori Business' as characterised by corruption, failure and dependence.

The fact that only a fraction of this paltry coverage was published in the business sections of newspapers seems to reiterate the idea that Māori business is still political and not the mundane, everyday commercial activity that fills the business section. It could also be that these are stories which make it to print for their novelty value rather than as part of the commercial culture of 
the country. There is a sense that Māori knowledge, innovation, energy and experience is not of interest to the wider business community that reflects the notions of privilege and threat evident in some of the items examined.

The thematic analysis reveals a wide range of positive stories about Māori commercial success and innovation. The diverse sectors covered and the different scale of business activities are rightly cause for acclaim and celebration and the papers that run them can be applauded. However, why are there so few? And why are they not in the business pages? The underpinnings of 'Maori Business' discourses work their poison because the vital context of colonial asset stripping from Māori communities is never articulated. The nuanced undermining and denigration that we have described feeds off what Philo (2007:183) has referred to as the 'wider systems of ideologies which informed social understanding, the stock of ideas, imagery, tropes and patterns of discourse that resource, locate and render meaningful, particular interpretations of news.'

These issues are of concern both for the light they cast upon media news values and for their potential and real impacts on both Māori and Pākehā in this country. Our associated audience studies (Gregory et al., 2011) combine with earlier research (Rankine et al., 2008) to demonstrate that media coverage of Māori adversely affects the sense of wellbeing of Māori individuals and communities. It also suggests that coverage reinforces societal and interpersonal racism and undermines social cohesion by rendering Pākehā less competent in their dealing and relationships with Māori (Nairn, 2010).

There are real contributions that mass media could be making to Māori/Pākehā relations that are foregone when the public good roles of journalism are subsumed within the commercial imperatives of contemporary media culture. Telling more Māori stories about business and commerce, telling them more positively outside of the hegemonic talk of privilege, inferiority and without recourse to the denigratory 'Maori Business' theme, would be an excellent start.

NOTES

1 This phrase and similar imagery are commonly used to signify under-developed Maori land.

\section{REFERENCES}

Ballara, A. 1986 Proud To Be White: A Survey of Racial Prejudice in New Zealand. Auckland: Heinemann. 
Belich, J. 1986 The New Zealand Wars and the Victorian Interpretation of Racial Conflict. Auckland: Auckland University Press.

Belich, J. 1996 Making Peoples: A History of the New Zealanders from Polynesian Settlement to the End of the Nineteenth Century. Auckland: Penguin.

Colvin, G. 2010 The Soliloquy of Whiteness: Colonial Discourse and New Zealand's Settler Press 1839-1873. University of Canterbury.

Devlin, M. 2007 'Māori entrepreneurship: fact or fallacy?', International Journal of Entrepreneurship and Small Business, 4 (4):407-418.

Durie, M. 1998 Te Mana, Te Kawanatanga: The Politics of Māori Self-Determination. Auckland: Oxford University Press.

Earle, E. 1909 A Narrative of a Nine Month's Residence in New Zealand in 1827. Wellington: Whitcombe and Tombs.

Fairclough, N. 1995 Media Discourse. London: Arnold.

Frederick, H. and Henry, E. 2004 'Innovation and entrepreneurship amongst Pākehā and Māori in New Zealand', in Stiles, C. and C. Galbraith (eds) International Research into the Business Disciplines (Vol. 4, Ethnic Entrepreneurship: Structure and Process). Amsterdam: Elsevier.

Gerbner, G. 1972 'Violence in television drama: trends and symbolic functions', in Comstock, G. and E. Rubinstein (eds) Media Content and Controls. Washington, DC: US Government Printing Office.

Gregory, A., Borell, B., McCreanor, T., Moewaka Barnes, A., Abel, S., Nairn, R., Rankine, J., Kaiwai, H. and Taiapa, K. (2010) 'Reading news about Maori; Responses from non-Maori media audiences', AlterNative, 7, 1, 51-65.

Jackson, M. 2007 'Globalisation and the Colonising State of Mind', in Bargh, M. (ed) Resistance: An Indigenous Response to Neoliberalism. Wellington: Huia Publishers. Wellington: Huia Publishers.

King, M. 2003 The Penguin History of New Zealand. Auckland: Penguin.

Lacy, S., Riffe, D., Stoddard, S., Martin, H. and Chang, K.-K. 2001 'Sample size for newspaper content analysis in multi-year studies', Journalism and Mass 
Communication Quarterly, 78(4):836-845.

Liu, L. 2009 'The Representation of Māori in Local Language News Media in New Zealand', Journal of Intercultural Studies, 30 (4):403-429.

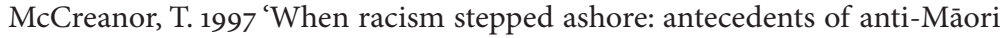
discourse in New Zealand', New Zealand Journal of Psychology, 26:43-57.

McCreanor, T. 2008 'Discourse, media and health in Aotearoa', in Dew, K. and A. Matheson (eds) Understanding Health Inequalities in Aotearoa New Zealand. Dunedin: University of Otago Press: 85-96.

McCreanor, T. 2009 'Challenging and countering anti-Māori discourse : practices for decolonisation', Psychology Aotearoa, 1 (1):16-20.

McIntosh, A., Zygadlo, F. and Matunga, H. 2004 'Rethinking Māori tourism', Asia Pacific Journal of Tourism Research, 9 (4):331-351.

McLintock, A. 1958 Crown Colony Government in New Zealand. Wellington: Government Printer.

Nairn, R., et al. 2010 'Mass media, an obstacle to cultural competence', New Zealand Journal of Psychology, submitted.

Nairn, R. and McCreanor, T. 1991 'Race talk and common sense: patterns in Pākehā discourse on Māori/Pākehā relations in New Zealand', Journal of Language and Social Psychology, 10 (4):245-262.

Nicholas, J. 1817 'Narrative of a voyage to New Zealand, performed in the years 1814 and 1815 in company with the Rev. Samuel Marsden'. London: J. Black.

Petrie, H. 1998 The 'lazy Māori' : Pākehā representations of a Māori work ethic 1890-1940. Unpublished A thesis submitted in partial fulfilment of the requirements for the degree of Master of Arts in History, University of Auckland.

Petrie, H. 2006 Chiefs of Industry: Māori Tribal Enterprise in Early Colonial New Zealand. Auckland: Auckland University Press.

Philo, G. 2007 'Can discourse analysis successfully explain the content of media and journalistic practice?', Journalism Studies, 8 (2):175-196 
Polack, J. 1974 New Zealand: being a narrative of travels and adventures: during a residence in that country between the years 1831 and 1837. Christchurch: Capper Press.

Potter, J. and Wetherell, M. 1987 Discourse Analysis and Social Psychology: Beyond Attitudes and Behaviour. London: Sage.

Rankine, J., Nairn, R., Moewaka Barnes, A., Gregory, M., Kaiwai, H., Borell, B., et al. 2008 Media \& Te Tiriti Waitangi 2007. Tamaki Makaurau/Auckland: Kupu Taea: Media and Te Tiriti Project.

Robson, B. 2007 'Economic determinants of Māori health disparities', in Bargh, M. (ed) Resistance: An Indigenous Response to Neoliberalism. Wellington: Huia Publishers.

Salmond, A. 1991 Two Worlds: First Meetings Between Māori and Europeans 16421772. Auckland: Viking.

Simpson, T. 1986 Te Riri Pakeha: The White Man's Anger. Auckland: Hodder and Stoughton.

Spoonley, P., MacPherson, C., Pearson, D. and Sedgwick, C. 1984 Tauiwi: Racism and ethnicity in New Zealand. Palmerston North: Dunmore Press.

Spurr, D. 1993 The Rhetoric of Empire. Durham Duke University Press.

Te Ara, 2011, Fishing Industry: Who owns quota? Retrieved from http://www. teara.govt.nz/en/fishing-industry/7

Te Puni Kōkiri, 2011, The Māori Commercial Asset base. Retrieved from http:// www.tpk.govt.nz/en/in-print/our-publications/publications/for-Māorifuture-makers/download/tpk-commercialassetbase-2007-en.pdf

Thompson, R. 1954 'Māori affairs and the New Zealand Press, Part II', Journal of the Polynesian Society, 63(1):1-16

Van Dijk, T. 1988 'How they hit the headlines: ethnic minorities in the press', in Smitherman-Donaldson, G. and T. Van Dijk (eds) Discourse and discrimination. Detroit: Wayne State University Press.

Walker, R. 1990 Ka Whawhai Tonu Matou. Auckland: Penguin. 
Article $\cdot$ McCreanor, McManus, Moewaka Barnes, Rankine, Borell \& Nairn

Walker, R. $2004 \mathrm{Ka}$ whawhai tonu matou, Struggle without end. Auckland: Penguin.

Ward, J. 1839 Information Relative to New Zealand. London: J.W. Parker. 